on the executives at Ottawa and Victoria and was president of that national society for the years 1928-29. He also sponsored a series of popular astronomical articles for the Press, and the revenue from these articles was devoted to a trust fund for the encouragement of amateur astronomy under the auspices of the Society. For many years he gave monthly radio talks on astronomical topics which did much to stimulate interest in the subject throughout the Dominion and even farther afield.

Dr. Harper's services to astronomy were well recog. nized throughout the astronomical world. In 1913 he was made a fellow of the Royal Astronomical Society of Canada. In 1924 he was elected to the Royal Society of Canada, and in 1935 the University of Toronto, on the occasion of the dedication of the David Dunlap Observatory, conferred on him the degree of doctor of science. In 1938 he was appointed as official Canadian delegate to the General Assembly of the International Astronomical Union at Stockholm. It was while absent on this trip that he was taken seriously ill with pneumonia. For several weeks he lay critically ill in Rostock Hospital and the international crisis finally necessitated his removal by ambulance to Denmark and thence to England. He returned to Canada in October somewhat improved and attempted to carry on, but suffered a serious relapse the following spring which a year later proved fatal. In his death, Canada has lost a very worthy citizen and a distinguished man of science.

R. K. Young.

\section{Mr. R. M. Wilson}

The sudden death on September 15 of Mr. Robert Melville Wilson, principal of the South-Eastern Agricultural College at Wye, has removed a notable figure from the British agricultural educational world.

Mr. Wilson was fifty-four years of age. He graduated at the University of Edinburgh and gained the national diploma in dairying. He obtained a Carnegie scholarship for research in mycology at the Heriot Watt College, Edinburgh, and in 1910 became a lecturer in agriculture for East Lothian and Peebleshire. In 1911 he became lecturer in agriculture and dairy farming at the East Anglian Institute of Agriculture, Chelmsford, where he performed splendid work in enhancing the reputation of the Winter School and Dairy School. In 1914, after holding an inspectorship in the Education Branch of the (then) Board of Agriculture, Mr. Wilson returned to the East Anglian Institute as principal and agricultural organizer for Essex. Several administrative appointments were held concurrently with the principalship at Chelmsford, and in $1920 \mathrm{Mr}$. Wilson was elected a member of the Council of Agriculture for England.

In October 1922 on the resignation of Principal M. J. R. Dunstan, Mr. Wilson was appointed to the principalship of the South-Eastern Agricultural College at Wye. From the day of his arrival Mr. Wilson continued to build the reputation of the College both as an educational and research centre. His constant interest in every aspect of the College's many activities was evinced by the enthusiasm with which he described to others the work that the various members of his staff were doing. He was always ready to devote time and energy to solving the difficulties of research workers, teachers and students alike, and was never too busy to discuss with any member of the College the problems or interests of his particular branch of study or research, and to bring the keenness and enthusiasm of his own nature to bear with vitalizing encouragement upon the question at issue. At all times Mr. Wilson was an idealist, he expected the best and believed the best of everybody. He was a great believer in the educational value of the pursuit of the solution of original problems in horticulture and agriculture and he encouraged students to take this view in their work. He kept in close contact with old students and was enthusiastic about their successes and ever ready to help them to progress in their careers.

At the outbreak of War Mr. Wilson threw himself into the task of training members of the Women's Land Army, and the kindly and understanding way in which he carried this out was much appreciated. It was a great satisfaction to him to re-open the College in January for the ordinary courses and a corresponding disappointment when it was found impossible to continue this autumn. He felt deeply the break with students and with members of his various staffs who were taking up new work, and no doubt this told heavily upon him. One who never spared himself, he was loved and respected by all who knew him, and heartfelt sympathy goes out to Mrs. Wilson and members of the family in their bereavement.

WE regret to announce the following deaths :

Prof. Max Cloetta, formerly director of the Pharmacological Institute, University of Zurich, aged seventytwo.

Mr. E. P. Van Duzee, curator of the Department of Entomology, California Academy of Sciences, on June 2, aged seventy-nine.

Prof. J. Goldschmidt, formerly director of the Berlin Institute of Criminology, aged sixty-six.

Sir Robert Hadfield, Bart., F.R.S., metallurgist and industrialist, on September 30, aged eighty-one.

Mr. F. C. Hart, manager of the Optical Lantern Department of Messrs. Newton and Co., Ltd., scientific instrument makers, on September 4, aged sixty-three.

Mr. F. H. Hooper, formerly editor of the "Encyclopædia Britannica", manager during the War of 1914-18 of the New York office of the Ministry of Food, on August 16, aged seventy-eight.

Mr. Cherry Kearton, the pioneer in popular natural history photography, on September 27, aged sixty-nine.

Colonel J. J. M. Shaw, consulting surgeon to the Army of the Middle East, a member of the National Radium Commission, aged fifty-four. 